\title{
Are green caterers more likely to serve healthy meals than non-green caterers? Results from a quantitative study in Danish worksite catering
}

\author{
BE Mikkelsen ${ }^{1, *}, M_{\text {Bruselius-Jensen }}{ }^{1}$, JS Andersen ${ }^{2}$ and A Lassen ${ }^{1}$ \\ 'Department of Nutrition, Danish Institute for Food and Veterinary Research, Mørkhøj Bygade 19, \\ DK-2860 Søborg, Denmark: ${ }^{2}$ Department of Epidemiology and Risk Assessment, Danish Institute for \\ Food and Veterinary Research, Søborg, Denmark
}

Submitted 24 August 2005: Accepted 21 November 2005

\begin{abstract}
Objective: The present study aimed to investigate whether organic conversion in catering has positive effects on the nutritional quality of menus offered.

Design: The methodology was based on a self-administered questionnaire. The selfdeclared priority given to the use of organic foods was measured as the basis for assigning catering managers to one of two groups: 'green' or 'non-green' caterers. These groups were then compared with regard to the relative nutritional quality of the menu options offered to customers.

Setting: The study was carried out among randomly selected Danish worksite catering outlets.

Subjects: The subjects participating in the study comprised 526 Danish worksite catering managers.

Results: The results showed a strong correlation between caterers' 'green-ness' and the nutritional quality of the menu options offered. Green caters had more healthy options in their menus than non-green caters, which is likely to result in improved nutritional quality of the diets of end consumers. The reason for this may partly be the increased service training efforts that green caterers practise in order to be able to implement organic foods successfully. It may also be associated with the fact that the price premiums and availability of the organic products forces caterers to serve menus with higher amounts of root and non-green leafy vegetables, pulses and seasonal vegetables.

Conclusion: The present findings suggest that organic conversion of public canteens may be a good opportunity to promote healthier eating in public catering.
\end{abstract}

Keywords
Catering
Healthy eating
Organic foods

Worksite
Organic food and farming are generally accepted and recognised as being able to deliver public goods for society as stated in the 2004 action plan of the European Commission $^{1}$ and many countries are actively supporting organic food production. Although the development is driven primarily by environmental concerns, there is substantial interest in the health implications of consuming organic foods. According to Beckmann ${ }^{2}$, the most important reason for Danish consumers to buy organic products is health (45\%), reported as more important than concerns for the environment and nature (39\%). In the European context also health reasons are the most important reason for choosing organic foods ${ }^{3}$. Although consumers' notion of health is complex and includes a whole range of parameters such as contents of pesticides and fertilizer residues, it is fair to assume that consumers also expect organic foods to be associated with improved nutrition.
The health and nutritional effects of consumption of organic foods have been the focus of attention in the scientific community for some time, and attempts have been made to compare organic foods with conventional foods in the search for differences in substances that might have a beneficial effect on nutrition. These approaches have focused on differences related to the foods themselves. Several reviews ${ }^{4-6}$ have concluded that organic vegetables are characterised by higher contents of vitamin $\mathrm{C}$ and dry matter, and often higher contents of minerals and secondary metabolites, compared with conventional vegetables. However, the studies also point out that most of these differences might be of only minor nutritional significance when viewed in a broader dietary context.

Instead of looking for nutritional benefits resulting from the composition of organic foods, it could therefore be of more relevance to test whether any possible nutritional 
benefits arise from the changed dietary pattern resulting from the transitions taking place in connection with the shift from conventional to organic consumption. As pointed out by O'Doherty et al. ${ }^{6}$, heavy users of organic foods seem to have dietary habits that are distinctly different from those of non-heavy users and these dietary habits might comply more easily with existing nutritional recommendations.

The most important users of organic foods are caterers in public institutions such as homes for the elderly, kindergartens, schools and workplaces ${ }^{7-10}$. In Denmark approximately $30 \%$ of institutions and $50 \%$ of municipalities ${ }^{11}$ have been involved in the conversion to organic catering within the last six years. Since these organic conversions have included substantial changes of menus ${ }^{12}$, it can be assumed that these conversions might have a substantial impact on the nutritional quality of the diets offered at these institutions.

From a consumer perspective it is relevant to consider whether the choice that the public or private caterer makes on behalf of the client in favour of organic foods might induce any spin-off effects in terms of healthier eating, especially since the idea that the public should take the lead and set a good example in organic food consumption is gaining general support at policy-making level in many countries $^{13}$. According to the European action plan on organic food and farming, priority is given to organic foods in public institutions ${ }^{1}$.

The aim of the present study was to assess whether organic conversion in catering has positive effects on the nutritional quality of the menus offered. To investigate this, a survey of the serving frequency of healthy menu items was carried out with the aim of determining whether being a green caterer had any association with the menu options available and thus the dietary practices in these catering facilities. On the basis of the findings, the nutritional implications of organic conversion in public catering are discussed.

\section{Methodology}

Worksite catering sites were chosen as the setting. An analysis was carried out on data from a questionnairebased study among worksite caterers focusing on the nutritional quality of menu options and their self-reported priority given to organic foods. The questionnaire was part of a larger study on attitudes, routines and habits in relation to healthy eating and nutrition.

The questionnaire was sent out in September 2003 to 1967 canteen managers randomly selected among the 3800 records available on the database of the Canteen Managers Association. Of these, 75 questionnaires were either returned to sender because the address was unknown or returned with a note that the survey was not relevant for that particular catering manager. In total 526 individuals responded to the questionnaire, a response rate of $28 \%$.
Besides answering questions about their attitude and habits, the respondents provided information on the characteristics of their own catering outlet.

To analyse the data, respondents were assigned to either a 'green' or a 'non-green' group based on the self-declared priority given to the use of organic foods. The two groups were then compared with regard to the relative nutritional quality of the menu options offered to customers.

The green group comprised those respondents who reported that using organic foods had a special priority or was very important or rather important. Likewise, the non-green group comprised those respondents who answered that using organic foods was either not that important or not important at all. In the sample 63 caterers were assigned to the green group and 463 to the nongreen group.

Using the same approach and based on answers about the serving frequency of different menu items, a bealthy menu option was defined for 13 different menu items. The healthy label was assigned in each of the 13 cases if a particular healthy option was available every day or 3-4 times a week, in contrast to if that option was available only 4-8 times a month, seldom or never. Meal patterns in Denmark are based on adults normally having their lunch at the worksite around noon and lunch is based on one or more of the following dishes: cold open sandwiches, salads, smaller hot dishes, fruit, snacks and cakes. The menu items chosen for the present study fell into three categories: open sandwiches, hot dishes, and salads, fruit and snack vegetables as listed below.

For the open sandwich category, the healthy options were low-fat, fish, vegetables, 'no butter' and 'no mayonnaise'. For the hot dishes category, the healthy options were hot dish complying with the 'plate model', hot fish dish and hot vegetable dish. For the salads, fruit and snack vegetables category, the healthy options were ready-made salads, 'mix it yourself' salad, root and nongreen leafy vegetables, pulses and seasonal vegetables for salads; fresh fruit in pieces and whole fresh fruit; and servings of snack vegetables.

The two-by-two tables were analysed in R programming language using a chi-square test with Yates continuity correction. The adjustments for multiple testing of $P$-values were carried out according to Benjamini and Hochberg ${ }^{14}$. Two-sided $P$-values $<0.05$ were considered significant.

\section{Results}

The prevalence of healthy options among green caterers compared with non-green caterers is shown in Tables 1-3 respectively for the three categories of menu option: open sandwiches, hot dishes, and salads, fruit and snack vegetables. $P$-values exceeding 0.20 are not included in the tables. The results show that in 12 out of 13 cases, the availability of healthy menu options was greater among 
Table 1 Prevalence of availability of healthy menu options in the open sandwiches category among green and non-green caterers

\begin{tabular}{lccc}
\hline Healthy & $\begin{array}{c}\text { Green } \\
\text { menu option }\end{array}$ & $\begin{array}{c}\text { Non-green } \\
(n=463)\end{array}$ & $P$-value \\
\hline $\begin{array}{c}\text { Serving of low-fat } \\
\text { open sandwiches (\%) } \\
\begin{array}{c}\text { Serving of fish for } \\
\text { open sandwiches (\%) }\end{array}\end{array}$ & 73 & 63 & \\
$\begin{array}{c}\text { Serving of vegetables for } \\
\text { open sandwiches (\%) } \\
\text { Existence of a 'no butter' } \\
\text { choice option (\%) }\end{array}$ & 46 & 21 & $<0.001$ \\
$\begin{array}{c}\text { Existence of a 'no } \\
\text { mayonnaise' choice option (\%) }\end{array}$ & 92 & 80 & 0.068 \\
\hline
\end{tabular}

green caterers than among non-green caterers. In seven of these 12 cases the differences were statistically significant.

Three healthy menu options were strongly significantly associated with being a green caterer: 'serving of vegetables for open sandwiches', 'serving of fresh fruit in pieces' and 'serving of hot vegetable dishes' $(P<0.001)$. Furthermore, the menu options 'serving of hot fish dishes', 'serving of root and non-green leafy vegetables, pulses and seasonal vegetables for salads', 'existence of a no mayonnaise option' and 'serving of snack vegetables' were significantly associated with being a green caterer.

The fact that there are many significant differences in the menus served by the green and the non-green caterers cannot be explained by the general characteristics of the two groups, as illustrated in Table 4 . The green caterers did not differ considerably from the non-green. However, the exceptions were rural/urban setting, in-service training of employees and the adoption of a food and nutrition policy as shown in Table 4 . The green caterers received more financial support from the company than the non-green caterers.

\section{Discussion}

The main finding of our study is that green caterers make healthy options available for customers more frequently than non-green caterers. Moreover, the present results indicate that there is an association between being green and caring about healthy eating issues.

Table 2 Prevalence of availability of healthy menu options in the hot dishes category among green and non-green caterers

\begin{tabular}{lcccr}
\hline $\begin{array}{l}\text { Healthy } \\
\text { menu option }\end{array}$ & $\begin{array}{c}\text { Green } \\
(n=63)\end{array}$ & $\begin{array}{c}\text { Non-green } \\
(n=463)\end{array}$ & $P$-value \\
\hline $\begin{array}{lccc}\text { Serving of hot meals } \\
\quad \text { according to the "plate model** (\%) }\end{array}$ & 63 & 60 & \\
$\begin{array}{l}\text { Serving of hot fish dishes (\%) } \\
\text { Serving of hot vegetable dishes (\%) }\end{array}$ & 22 & 10 & 0.034 \\
\hline
\end{tabular}

* The 'plate model' is a way to illustrate a serving that complies with official nutritional recommendations. In the model, the letter $Y$ divides the plate into three sections. According to the model, meat, cheese, fish and eggs should then account for $1 / 5$ of the plate, fruit and vegetables should account for $2 / 5$, and rice, pasta, potatoes and bread should account for $2 / 5$.
Table 3 Prevalence of availability of healthy menu options in the salads, fruit and snack vegetables category among green and non-green caterers

\begin{tabular}{lccc}
\hline $\begin{array}{l}\text { Healthy } \\
\text { menu option }\end{array}$ & $\begin{array}{c}\text { Green } \\
(n=63)\end{array}$ & $\begin{array}{c}\text { Non-green } \\
(n=463)\end{array}$ & $P$-value \\
\hline $\begin{array}{l}\text { Serving of ready-made } \\
\text { salads (\%) }\end{array}$ & 59 & 53 & \\
$\begin{array}{l}\text { Existence of a 'mix it yourself' } \\
\text { salad (\%) }\end{array}$ & 75 & 78 & 0.034 \\
$\begin{array}{l}\text { Serving root and non-green } \\
\text { leafy vegetables, } \\
\text { pulses and seasonal } \\
\text { vegetables for salads (\%) }\end{array}$ & 79 & 62 & \\
$\begin{array}{l}\text { Serving of fresh fruit } \\
\text { in pieces (\%) }\end{array}$ & 54 & 31 & $<0.001$ \\
$\begin{array}{l}\text { Serving of whole } \\
\text { fresh fruit (\%) }\end{array}$ & 86 & 77 & 0.155 \\
$\begin{array}{l}\text { Serving of snack } \\
\text { vegetables (\%) }\end{array}$ & 60 & 43 & 0.038 \\
\hline
\end{tabular}

Organic conversion of public canteens has become mainstream in many countries and at the same time nutrition issues have become an important priority ${ }^{15,16}$. Therefore further focus on the nutritional implications of organic conversion seems relevant.

Our findings indicate that giving priority to organic foods may lead to changes in the catering unit that may result in healthier menus. This improved availability of healthy choices in turn is likely to result in healthier dietary behaviour among customers.

Table 4 Characteristics of the green caterers compared with the non-green caterers

\begin{tabular}{|c|c|c|c|}
\hline $\begin{array}{l}\text { Characteristics } \\
\text { of the respondents }\end{array}$ & $\begin{array}{l}\text { Green } \\
(n=63)\end{array}$ & $\begin{array}{l}\text { Non-green } \\
(n=463)\end{array}$ & $P$-value \\
\hline Situated in urban settings (\%) & 61 & 43 & 0.014 \\
\hline Canteen outsourced (\%) & 27 & 25 & NS \\
\hline $\begin{array}{l}\text { Company has a food and } \\
\text { nutrition policy (\%) }\end{array}$ & 36 & 20 & 0.011 \\
\hline \multicolumn{4}{|l|}{ Characteristics of canteen staff } \\
\hline $\begin{array}{l}\text { Mean number of employees } \\
\text { in canteen }\end{array}$ & 4.2 & 4.1 & NS \\
\hline $\begin{array}{l}\text { Mean proportion of unskilled } \\
\text { canteen workers (\%) }\end{array}$ & 71 & 70 & NS \\
\hline $\begin{array}{l}\text { In-service training having } \\
\text { a high priority (\%) }\end{array}$ & 75 & 56 & 0.002 \\
\hline \multicolumn{4}{|l|}{ Characteristics of canteen } \\
\hline $\begin{array}{l}\text { Mean number of daily } \\
\text { canteen users }\end{array}$ & 174 & 159 & NS \\
\hline $\begin{array}{l}\text { Mainly }(75-100 \%) \text { sedentary } \\
\text { job functions at worksite (\%) }\end{array}$ & 52 & 54 & 0.090 \\
\hline $\begin{array}{l}\text { Mainly }(75-100 \%) \text { female } \\
\text { employees at worksite (\%) }\end{array}$ & 16 & 9 & NS \\
\hline \multicolumn{4}{|l|}{ Canteen subsidised by company } \\
\hline Foods (\%) & 33 & 22 & 0.097 \\
\hline Furniture and equipment (\%) & 69 & 68 & NS \\
\hline Salary (\%) & 72 & 62 & NS \\
\hline \multicolumn{4}{|l|}{ Types of serving ${ }^{*}$} \\
\hline In-line counter (\%) & 44 & 50 & NS \\
\hline Free flow buffet (\%) & 72 & 71 & NS \\
\hline
\end{tabular}

NS - not significant.

* Some canteens utilise several types of serving. 
The results show that green caterers use vegetables in their menus more extensively than their non-green counterparts. This is seen in the four healthy options of serving of vegetables for open sandwiches, serving root and non-green leafy vegetables, pulses and seasonal vegetables for salads, serving of snack vegetables and the hot vegetable dish option. This can be explained partly by the fact that organic products carry a price premium compared with non-organic products. Thus to finance the price premium organic caterers are likely to rearrange their menus, looking to include more roots and legumes and at the same time reducing the meat content since these products carry the smallest price premium when bought organic $^{17}$. This rearranging of menus towards the use of more roots and legumes has become a frequently used option in organic conversion projects ${ }^{18,19}$. In fact, most organic catering projects have been characterised by using a conversion approach involving substantial re-engineering of routines rather than a simple substitution approach in which conventional products are simply substituted one by one ${ }^{20}$.

Also, the frequent option of fish dishes among green caterers can be explained by cost concerns. Fish is often a cheaper alternative to organic meat and fish is generally accepted as part of an organic menu, even though fish is not certified organic.

The finding of more non-fat options in organic menus cannot be explained by the price premium, nor can the fact that the green caterers serve more fruit, especially cut fruit. These findings indicate that green caterers are more conscious about the nutritional composition of their menus. This indication is supported by the fact the green caterers offer significantly more in-service training and that food policies are significantly more frequently found among green caterers.

It should be noted that the present study measured selfdeclared priority given to the use of organic foods rather than the extent to which the caterers actually use organic food products. It is well recognised that differences exist between attitudes and behaviour in relation to consumption of organic foods and this is a weakness of the present study. However, we have no reason to believe that this difference should be different in the two study groups.

Another weakness of the present study that cannot be excluded is the rather low response rate, which might lead to an overrepresentation of committed caterers who take their tasks more seriously and thus be more willing to respond.

Examples of the linking of organic procurement schemes with dietary changes in catering can be found in a number of counties. In an Austrian organic conversion project $^{21}$ that targeted hospital employees and patients, the plan was aimed at reducing the amount of pork and increasing the amount of seasonal vegetables and fruit products in order to make its implementation economically feasible. The Swedish Eat Smart campaign ${ }^{22}$ found that increasing share of organic foods in institutions was linked to increased intakes of high-fibre vegetables, seasonal fresh fruit and vegetables, increased share of vegetables and decreased amount of empty calories. In the Norwegian Organic Catering Project at Trondheim hospital, the organic conversion was combined with substantial menu changes focusing on more vegetables and fruit and stricter use of meat ${ }^{23}$.

According to O'Doherty et $a l^{6}{ }^{6}$, implementation of organic procurement policies in catering forces institutions to adapt to new conditions. Caterers are forced to adapt their menu plans and recipes to match the processing level of organic foods, change their production routines to adapt to the current supply of organic products, and make changes to menu plans and recipes to adapt to the price premium. The authors suggest that these changes fit well with current dietary recommendations.

In an evaluation of the Danish support programme for organic foods in catering, $74 \%$ of project managers stated that in-service training of kitchen staff in food and nutrition was included and $89 \%$ of projects were aiming to make concrete changes towards serving healthier menus $^{24}$. In a qualitative study of Danish municipal institutions, Mikkelsen et al. $^{12}$ found that the organic conversion processes were characterised by adoption of nutrition policies and in-service training of staff in nutritional assessment of menu plans. In projects aimed at implementing organic foods covering 99 Danish schools, it was found that four out of five projects had in-service training of school food staff in nutrition as an integrated activity ${ }^{25}$. A similar pattern was found in a sample of organic worksite projects, where five out of seven were aiming explicitly at promoting healthy eating and included in-service training in nutrition ${ }^{25}$.

Rasmussen and Mikkelsen ${ }^{26}$ examined selected indicators for healthy eating in a study of day-care institutions serving organic foods. They found that such indicators in the organic institutions included having a nutrition committee, having adopted a food and nutrition policy, having nutrition as a fixed issue on staff meeting agendas, having adopted a skilled-catering-staff-only policy, and having policies and procedures for in-service training of catering employees in nutrition.

The present findings suggest a correlation between caterers' preferences and positive attitudes towards using organic food products in their canteens and the nutritional quality of their menu style. This may partly be a result of the increased in-service training efforts that green caterers practise in order to successfully implement organic foods. It may also be connected to the fact that the price premiums and availability of the organic products result in more roots, legumes and seasonal vegetables in the menus. The present study also showed that fish is served more often instead of the more expensive and less available organic meat.

The implication of the present study for public health professionals and nutritionists is then to consider if organic conversion is automatically connected with using more 
vegetables and fruit and more fish. If this is the case, then organic conversion seems a promising way of promoting healthier menus in public eating.

\section{References}

1 European Commission. Action Plan for Organic Food and Farming. Brussels: European Commission, 2004.

2 Beckmann S. ØKO foods revisited - Danish consumers demand for organic food at the turn of the century. In: Farhangmehr M, ed. Proceedings of the 31st EMAC Conference. University of Minho, Braga, 2002.

3 Torjusen H, Sangstad L, O'Doherty JK, Kjærnes U. European Consumers' Conceptions of Organic Food: A Review of Available Research. Professional Report No. 4. Oslo: National Institute for Consumer Research, 2004.

4 Agence Francaise de Sanite et Securite Alimentaire. Evaluation des risques et bénéfices nutritionnels et sanitaires des alimints issus de l'agriculture biologique. Paris: Agence Francaise de Sanite et Securite Alimentaire, 2003.

5 Soil Association. Organic Farming, Food Quality and Human Health. Bristol: Soil Association, 2002.

6 O'Doherty Jensen K, Larsen HN, Mølgård JP, Andersen JO, Marckmann $\mathrm{P}$, et al. Organic Food and Human Health. Frederiksberg: Research Institute for Human Nutrition, Royal Veterinary and Agricultural University, 2001 [available in Danish only].

7 Laberenz H, Naatz OW. Biogerichte in Betriebsrestaurants Ökologie und Landbau 2000; 113: 39-40.

8 Mikkelsen BE, Kristensen NH, Nielsen T. Organic Foods in Catering - The Nordic Perspective. Søborg: Veterinary and Food Administration, 2002

9 Spiller A, Lüth M, Enneking U. Chancen und Potenziale von Öko-Lebensmitteln in der Außer-Haus-Verpflegung am Beispiel der Verzehrgewohnheiten von Mensa- und Kantinenbesuchern. Göttingen: Institut für Agrarökonomie, Lehrstuhl Marketing für Lebensmittel und Agrarprodukte, Georg August Universität, 2003.

10 Rimmington M. Organic food - too good to eat? Hospitality Review 2003; 5: 13-8.

11 Nielsen T, Kristensen NH, Mikkelsen BE. Use of Organic Foods in Municipalities and Counties. Søborg: Veterinary and Food Administration, 2002 [available in Danish only].

12 Mikkelsen BE, Pedersen TT, Therkildsen KN. A Lot More than Organic Foods - A Study of Motives and Effects of Organic Change Processes in Day Care Institutions. Søborg: Danish Institute for Veterinary and Food Research, 2004 [available in Danish only].
13 Rech T. Organic Food for Public Institutions. Organic Agriculture, Sustainability, Markets and Policies. Report from a Workshop on Organic Agriculture. Washington, DC: Organization for Economic Co-operation and Development, 2003; 401-40.

14 Benjamini Y, Hochberg Y. Controlling the false discovery rate: a practical and powerful approach to multiple testing. Journal of the Royal Statistical Society Series B 1995; 57: 289-300.

15 Guilland A. Nutrient based quality control in public catering: need for revision. Journal of Food Engineering 2003; 56 : 189-93.

16 European Commission. Health and Human Nutrition Element for European Action. Brussels: Société Francaise De Santé Publique/Présidence Francaise de l'Union Européenne/DG SANCO Health and Consumer Protection, 2000.

17 Hamm U, Gronenfeld F. The European Market for Organic Food: Revised and Updated Analysis. Aberystwyth: University of Wales, School of Management and Business, 2004.

18 Agger AB, Hansen TB, Leth KD, Mundt P, Sørensen L. Report on a Sustainable Food Development Project in Western Zealand Hospital. Valby: Aggers selskab, 2004 [available in Danish only].

19 Mikkelsen BE, Elle JC. Bericht aus Dänemark - Grosse küchen, grossen möchlichkeiten. Ökologie und Landbau 2005; 136: 42-4.

20 Mikkelsen BE, Kristensen NH, Nielsen T. Change processes in large scale public catering - case findings from implementation of organic foods in a Danish county. Foodservice Business Research 2005; 8: 87-105.

21 Holler C. Machbarkeitsstudie zur Maximierung des Einsatzes biologischer Lebensmittel in Großküchen. Salzburg: Umwelt Land Salzburg, 2001.

22 Lindeskog P. Food and environment in Stockholm county eat smart. Presentation at Workshop on Public Organic Food 13 October. Aas: Norwegian Food Research Institute, 2005. Also available at http://www.healthcat.net/Default.asp? $\mathrm{m}=8$

23 Solemdal L. A national pilot project on organic foods in large scale catering at St. Olavs Hospital in Trondheim [available in Norwegian only]. Presentation at Workshop on Public Organic Food, 13 October. Aas: Norwegian Food Research Institute, 2005. Also available at http://www.healthcat.net/Default.asp? $\mathrm{m}=8$

24 Direktoratet For Fødevare Erhverv. Evaluation of the Grant Scheme Green Purchasing. Copenhagen: Directorate for AgriBusiness, 2004 [available in Danish only].

25 Mikkelsen BE, Bruselius-Jensen M. Better nutrition in organic catering than in conventional? Programme and Abstracts of the 8th Nordic Nutrition Conference, 20-23 June. Tønsberg: University of Oslo, 2004.

26 Rasmussen SW, Mikkelsen BE. Is public organic food healthier? Ernaerings- og husholdningsøkonomen [The Home Economist] 2003; $812-5$ [available in Danish only]. 